\title{
"Work with Me, Not for Me": Malaysia under Abdullah Ahmad Badawi (2003-2009)
}

\author{
Sivamurugan Pandian \\ Anthropology and Sociology Section, School of Social Sciences \\ Universiti Sains Malaysia \\ 11800 Penang, Malaysia \\ E-mail: psiva@usm.my \\ Rusdi Omar \\ Department of International Studies, College of Law \\ Government and International Studies, Universiti Utara Malaysia \\ 06010 Sintok, Kedah, Malaysia \\ E-mail: rusdiomar@uum.edu.my \\ Mohd Azizuddin Mohd Sani \\ Department of International Studies, College of Law \\ Government and International Studies, Universiti Utara Malaysia \\ 06010 Sintok, Kedah, Malaysia \\ E-mail: azizuddin@uum.edu.my
}

\begin{abstract}
This paper examines the political and executive leadership in Malaysia, with reference to the fifth Prime Minister, Tun Abdullah Ahmad Badawi. The Prime Minister is an important autonomous actor, a leader of the government party who also manages public bureaucracy and utmost, Abdullah is seen as the leader of the people. Policy agenda depends on the Prime Minister's authority to either make an impact or bring changes. This paper will address the leadership style of Abdullah in the executive and policy-making and what kind of influence does he provide in policy-making and its implications in Malaysia's political environment.
\end{abstract}

Keywords: Abdullah Ahmad Badawi, Malaysia, United Malays National Organization, Barisan Nasional, Leadership, Islam Hadhari

\section{Introduction}

From the time Malaysia gained independence in 1957, the country has been under the respective leadership of six Prime Ministers, each possessing his own values and authority desirable to accommodate the needs and surroundings of which they led while in power. The fifth Prime Minister, Tun Abdullah Ahmad Badawi (Note 1) presided as the country's leader on October 31, 2003. This date plays a significant role in the Malaysia history of political leadership, due to firstly, the stepping down of the modern Malaysia's founding father; a statesman who had stood at the helm of the government for almost 22 years and had shaped the development of Malaysia. During the 2002 United Malays National Organization (UMNO) General Assembly, the country received the unexpectedly shocking announcement of the then Prime Minister, Tun Dr. Mahathir Mohamad's (Note 2) decision to retire, hence marking the start of a smooth process of political exchange of leadership and transition for the next 16 months. Also, this date was to be the starting point of yet another political journey; the leadership of Malaysia's fifth Prime Minister. 
This paper will attempt to study the factors which may be associated with the Abdullah's leadership style throughout his reign of five years. This paper will also attempt to study the aspect of personality and its implications towards attitude and behaviour of political leadership.

The following section will provide emphasis on the Abdullah's background and the history of his involvement into the world of politics which will help to evaluate how each phase of his life had great influence on his style of administrative leadership as the fifth Prime Minister of Malaysia.

\section{Who is Abdullah?}

Born on November 26, 1939 to the family of Ahmad Badawi and Kailan Hassan (Note 3) in Kampung Perlis, Bayan Lepas, he grew up in Kuala Kangsar where his father and grandfather held positions as religious teachers in Idrisiyah Madrasah before moving on to Kepala Batas. Abdullah received his education in Methodist Boys' School, Bukit Mertajam High School and Daeratul Maarif Wataniah Religious Secondary School, before proceeding to pursue the subject of Islamic Studies at the University of Malaya, from which he graduated in 1964.

From the year 1939 till 1964 formed the pioneer stage in the Abdullah's appearance and personality as his family background played a fairly large role in the context of his political leadership today. Compared to other leadership styles, Abdullah was greatly influenced by the religious backgrounds and knowledge of his father and grandfather, of which he inherited and further strengthened through the education he received while in the University of Malaya.

Meanwhile, the period of 1964 till 1976 is significant because it saw Abdullah serving as a civil servant holding several positions including Assistant Secretary in the Public Services Department; and Head Assistant Secretary in the National Operation Council (NOC); Director in the Ministry of Youth and Sports; and since 1974, Deputy Chief Secretary in the same ministry. In 1978, Abdullah tendered his resignation in the civil service as he had been elected as the candidate for Kepala Batas Parliament seat, the successor to his late father. (Note 4)

Stage three of Abdullah's life, being the duration of 1978-1987, indicated the initiation of his journey of a career in politics, after standing in the 1978 elections for the Kepala Batas Parliamentary seat succeeding his late father. Abdullah was then elected as Parliamentary Secretary and then Deputy Minister in the Federal Territory Ministry. Dr. Mahathir's succession as Prime Minister after Tun Hussein Onn in July 1981 was followed by Abdullah's appointment as a Minister, in which he held three portfolios till 1987, them being Minister in the Prime Minister's Department, Minister of Education and Minister of Defence respectively.

After nine years of being a Member of Parliament and serving in the Cabinet of Dr. Mahathir, Abdullah's political career seemed to have reached its end. The defeat of Team B, led by Tengku Razaleigh Hamzah, to Team A under the leadership of Dr. Mahathir, in the 1987 UMNO party elections was an extremely valuable experience in Abdullah's political career. Opting to be part of the team running against the very mentor who had ushered him into the Cabinet in 1981 proved to be one of Abdullah's biggest political decisions. This proved a huge risk for although Abdullah secured the position of Vice President, he was not selected to hold any positions in the administrative government under the leadership of Dr. Mahathir at that time (Wan Teh, 1993). The majority votes which Abdullah obtained did not mean that he was accepted by Dr. Mahathir, regardless of his number of votes exceeding those obtained by former Deputy Prime Minister, Datuk Seri Anwar Ibrahim, (Note 5) which appeared to be the second highest number of votes after Dato' Seri Amar Wan Mokhtar Ahmad, former Chief Minister of Terengganu. (Note 6)

Three years from 1987 till 1990 may be considered the fourth and most critical, chronic and perhaps saddest stage of Abdullah's political journey. Without strong confidence in defending a position, a leader would no doubt succumb to the challenge and turn to other venues. The inner confidence and strength within Abdullah generated him to succeed in overcoming barriers and challenges at this stage, specifically the effects toward Team B and secondly, the presence of opposition leaders in UMNO itself and the rise of Anwar Ibrahim. He was observed and labelled as the principal traitor of the leader's supporters who considered him as competition in Penang and central level. Abdullah used this 'sabbatical leave' (Wariya, 2004) to undergo a self-realisation process which then enabled him to obtain the highest position in the party and the government.

Abdullah decided to remain in the party along with other fellow supporters of Tengku Razaleigh, amidst the suggestion of others to do otherwise. This decision proved to be Abdullah's best decision. His loyalty to the party won Dr. Mahathir's trust and Abdullah was offered the opportunity to compete in the 1990 General Elections, and was subsequently elected to be part of the Cabinet; three years after he was dropped. (Note 7) There was the possibility that Abdullah was once again accepted not only because of the support of the party internally, but also as he was seen as the best candidate to balance the influence of Anwar Ibrahim who had then begun to grow.

The resumption of Abdullah under the administration of Dr. Mahathir led to the transition of a new phase. One decade from the year 1991 till 2003 proved to be a testing stage for Abdullah to obtain the utmost trust from Dr. Mahathir. Abdullah's genuine hope to continue serving and offering his loyalty to the party convinced Dr. Mahathir to maintain Abdullah's position in the Cabinet regardless of his failure to win the Vice President position in the 1993 UMNO 
elections. Although in 1987 he obtained the position in the party but was not elected to the Cabinet, in 1993 Abdullah was given a place in the Cabinet without having won any position in the party. His clean image from money politics which had begun to infiltrate the party at that time may be considered an indication towards Dr. Mahathir's decision to maintain Abdullah in the Cabinet. The events of 1987 and 1993 shaped Abdullah's leadership style today. Defeat, experience and the test of political games have all resulted in Abdullah gaining the level of maturity which has formed his style of leadership.

Although engaged with his duties as Minister of Foreign Affairs at that time, Abdullah succeeded in winning back the UMNO Vice President seat in the 1996 elections. (Note 8) After three years of holding the position, Abdullah gained the trust of Dr. Mahathir and was elected as the UMNO Deputy President in 1999 and Deputy Prime Minister, the fourth under the leadership of Dr. Mahathir following the dismissal of Anwar Ibrahim in 1998.

In Jun 2002, Dr. Mahathir shocked the delegation and the entire Malaysian public and the world with his announcement to retire, and announced his trust and belief in Abdullah as his successor.

\section{Abdullah as Prime Minister (2003-2009)}

Abdullah was the fifth Prime Minister of Malaysia from October 31, 2003 until April 3, 2009. No doubt, upon mentioning or discussing Abdullah's leadership style, it has to be referred to his position as Prime Minister, the keeper of the utmost power and authority in the Prime Minister's Office (PMO). This is because the Prime Minister is the highest rung of leadership in the country; he assimilates and portrays the image of the most important individual in the context of the country's administrative system. The power of the PMO allows the Prime Minister to form, implement and bring about large effects upon the agenda as well as the vision and mission of the country. A Prime Minister who possesses great capabilities and is accepted by many requires at least four important criteria, them being loyalty to the party; experience, specific leadership features and qualities; patience and tolerance in being a leader; a good track record and a background accepted by many in a multi-racial nation.

As President of UMNO, the most dominant party within the 13 power-sharing affiliated parties, he also holds the position of Chairman of the main party, Barisan Nasional (BN). He not only oversees the interest of UMNO, but also as Prime Minister, he is responsible for the people of Malaysia regardless of religion, ethnicity or gender. He believes that 'the time for championing parochial interests is over. Issues must be addressed on the basis of the interest of the nation and the Malaysian people as a whole' (New Straits Times, 9 November 2007). This clearly shows that besides being the President of the Malay nationalist party, he understands his position as leader for all Malaysians.

A leader requires legitimacy in his leadership during his time of being in power in order to form a mindset among his people and supporters to realise and understand their obligation to have the utmost loyalty to their leader (Weber, 1964). Supposing such realisation and understanding ceased to exist among followers for the need to obey, hence a rather loose relationship between the leader and his people would develop, and it would seem as if the leader had not any form of authority, thus allowing an open door for his legitimacy to be challenged or questioned.

Political legitimacy, if seen as 'a general acceptance by the public upon the political system' as pointed out by Lipset (1963), without influence from differences of opinion which places the trust of moral rights to lead, as averred by Muthiah Alagappa (1995), relies on several factors. Firstly, the history of power structure inherited by the relationship between the government and the people places strong influence on the actions of political leaders. Second, integration patterns incorporated with ethnic and religious identity influences the basic function of a political system. Next, the relationship formed between the economy and political change. Fourth, the role of ideas and visions, such as democratic ideology, freedom of speech, freedom of the media, and organisational freedom as the base for choice and measures taken which influences political results. Finally, any form of international influence in any possibilities or occurrences affecting the country. Based on these five factors, a clarification can be made on the legitimacy of Abdullah's political leadership throughout his five-year reign in administering the country which is directly connected to his practice of leadership style.

With his inheritance of a stable government, demands among members of the public increased. Political participation from various educated groups as well as the increase in the number of parties emphasising on materialistic lifestyles brought on a different atmosphere. It was evident at this point that the country was heading to a population which focused on an individualistic nature but simultaneously possessed a desire for freedom of speech and political liberty.

With such a context, Abdullah's emphasis on researching the achievements in maintaining a balance and steadiness of his predecessors during their reign of leadership formed a dilemma. To proceed with development plans based on previous agenda, but through new and different methods - would this be considered awkward or inept? According to Abdullah, the changes made in his rudiments of the government under his administration relied on facts and figures '..... what needs to be changed, what needs to be adjusted, all those are done based on facts and figures that we have taken into consideration' (New Straits Times, 21 June 2006). This new administration is actually based on the rise in the demands of the middle-class in order to be more open to changes. Throughout his five-year role in administration, his 
core emphasis has actually brought about a new awakening although it has been said that his goals are still to achieve and realise Vision 2020 and Mission 2057. Differences in backgrounds among the main leaders of the country previously greatly influenced the effects on world view, rudiments and his political legitimacy.

Abdullah was the fourth Deputy Prime Minister to Dr. Mahathir and had gained Dr. Mahathir's trust and confidence to lead the country after the latter's retirement. In actual fact, Abdullah was at first not entirely interested to pursue a career in politics as many around him were more comfortable and contented with Abdullah not holding a political position but instead to continue being in civil service and promoted to the highest position (Wariya, 2004, pp. 96-97). (Note 9) There were also those who recognised Abdullah's with the image of 'Mr. Clean' and 'Mr. Nice guy', thus leading to Abdullah receiving comments as a Prime Minister who was merely keeping the seat warm, or as a Prime Minister in transition awaiting his leadership duties to be taken over by his Deputy. (Note 10) After five years of being in power, there are also those who have made loud allegations and large criticisms stating that the Prime Minister had not made any changes whatsoever, when in fact, Abdullah has assured his fellow Cabinet members with his administrative and management skills, and his consensus leadership style as well as his negotiation tactics, that the allegations of being a 'seat warmer' and a single-term Prime Minister should be tossed aside (New Straits Times, 13 November 2006).

Whilst Abdullah began to take over the leadership of the country, many were concerned as to whether he was the right candidate to succeed Dr. Mahathir. This syndrome was nothing new; the same had occurred when the late Tun Hussein Onn succeeded the late Tun Abdul Razak and had his capabilities questioned by many. Upon Dr. Mahathir's succession to the Prime Ministerial seat after the late Tun Hussein Onn, a number of different reactions either supporting or against surfaced but it was clearly with no doubt that Dr. Mahathir was the best and most well-suited candidate who had the ability to cope with the surroundings at that time. After five years, would an identical label still be available or applicable to Abdullah?

After five years, we have become witnesses to an entirely new and different form and style of leadership, all of which can be associated with every phase of Abdullah's journey into the world of politics as to how it was explained in the beginning. Abdullah himself has stated - 'I have my own personal methods' and has admitted that - 'my style is most certainly to turn a deaf ear upon those who speak uncertainly. I prefer to focus my attention on work rather than to put up with unconstructive talk' (Mingguan Malaysia, 4 November 2007a). He realises that whatever decisions he makes will have a direct effect on the people and the nation, thus explaining that his decisions are not intentionally delayed but merely made after careful consideration and with much caution (Mingguan Malaysia, 4 November 2007b).

Many among the country's leaders are with the opinion that Abdullah should be given the opportunity to rule and lead according to his ways. For instance, his deputy Datuk Seri Najib Abdul Razak defends Abdullah's ruling methods with the belief that - 'each prime minister has his own style but what is important is that the head of the Government has strong support and can make decisions that benefit the people and country' (The Star, 19 September 2006).

Dato' Sri Sharizat Jalil has indicated that - 'Abdullah Ahmad Badawi must be given a chance now to provide leadership for Malaysia in his own style..... he is very consultative and all decisions made in cabinet were taken after long and lengthy discussions where everybody was given a chance to voice their opinions' (New Straits Times, 9 June 2006). Whilst Datuk Seri S. Samy Vellu has averred - 'Barisan Nasional parties are very confident of Abdullah's integrity ..... the people ratified Abdullah's leadership through the massive mandate received by the BN during the elections. As a Cabinet member, I can vouch that all Government decisions are made collectively' (New Straits Times, 9 June 2006).

Abdullah is assumed as portraying a rather open leadership style. There are those who see it as - '.... it's quieter. More circumspect. There's more introspection at the top; a need, as much as a willingness, to listen, perhaps even more than to speak. There's greater inclusion, more accommodation. Necessarily in these circumstances, and yet so easily depicted as indecisiveness, there's less unilateralism. And certainly, less of a hell-for-leather, gung-ho, we'll-do-it-our-way charge at the future' (New Straits Times, 9 June 2006). For MCA President, Datuk Seri Ong Ka Ting, '..... Abdullah had provided a clear direction and always adopted a democratic style by taking into consideration the views of Cabinet members and others when making decisions ... the people want a more open Government, not one that is autocratic where everything is controlled until no one is able to speak up' (The Star, 19 September 2006).

In looking on the style of leadership, there are three main components of Abdullah's leadership, i.e. participation, accommodation and consensus. The Table 1 below shows Abdullah's characteristics in his leadership style and importance of principles (see Table 1).

\subsection{Participation}

Participation is said to occur when it involves the people and leadership process. In his first meeting as Prime Minister at the Bayan Lepas International Airport, Abdullah is quoted to have said 'work with me and not for me', indicating the importance to put the needs and demands of the people first. As a political leader with the title of 'Prime Minister', Abdullah attempted to mobilise the support of the public by using the approach of 'cooperation and working together' 
and 'the people first, then myself' (Massa, 2004). This leadership style in fact enabled him to obtain a rather large majority in the past elections, the biggest majority ever perceived by BN until today (Pandian, 2006). (Note 11)

This large mandate reflected the political legitimacy on his leadership, however, after five years, there are those who are of the opinion that Abdullah has failed to fulfil the objective of his manifesto which he had declared during the 2004 elections, but to this, Abdullah simply states - 'the Barisan Nasional administration has fulfilled promises made in the last election. However, there is much more to be accomplished and the people need to give Barisan time' (The Star, 13 November 2007). His biggest challenge is to reverse the attitude of the people who desire instant decisions or results. In a meeting at a dinner held by the Chinese community in Penang to commemorate the country's 50th year of independence, Abdullah stated that all the promises made during the elections would be fulfilled and an approximation of 15 years would be needed to achieve the desired results.

This included the change of mindset among members of the civil service. Abdullah has made a number of unscheduled visits to several government agencies in order to ensure the upgrading and maintenance of good and quality civil service. Since his visits, several changes have been made to the quality of the civil service even though several complaints are still heard among consumers. These such changes include the Immigration Department's efforts to enable the process of renewing passports to take only 24 hours; the processing of contractors' applications by the Board of Industrial Construction Development has been shortened to 30 days; the Board of Internal Revenue is now able to process repayments in two days' time instead of the previous two-week duration, whilst the 14 various licences required for the hotel industry have now been combined into one licence, and almost 100 administrative systems are now using and offering online services, enabling less paper usage and shorter processing time (New Straits Times, 3 June 2006).

This clearly indicates the government's awareness of the importance of good and smooth implementation of civil services. Also to be considered is the government's success in resolving 98 percent of deals and works pertaining to land and property which had been left uncompleted and unsettled since 2001, and also to enable tax payments and refunds to be made via e-filing within the duration of 30 days (New Straits Times, 9 November 2007). With the formation of the Business Facilitation Special Task Force (Pemudah), a special task team formed with the joint efforts of 23 professionals from the private and public sectors to assist with business ventures, several approaches have already been introduced to increase and upgrade the service system. Business Licensing Electronic Support System (BLESS) is expected to be in operation soon to assist in processing approvals of business licences. Besides that, registration of new businesses can be done and completed within an hour and no longer three days as before; renewing of business licences to be done within 15 minutes instead of the previous one-day requirement, and the approval of manufacturing and production licence to take 23 days compared to the 40-59 day period previously practised.

Throughout the past five years, we have seen the Prime Minister allocate his administrative responsibilities to his ministries and agencies in order to allow them the experience and opportunity to bear the burden of their respective duties and roles. There are among many who consider this a weakness but it can also be seen as how Abdullah desires for everyone, as a team, to work together whilst performing individual and respective duties and tasks. Hence, they are responsible for executing and providing feedback not only via the media but also the development of the Cabinet.

'Doing his own thing', a label or tag given to Abdullah for the progress of his work relies on his ability to manage with his own personal style as mentioned above, all of which based on 'transparency, ethics, and responsibility' (New Sunday Times, 2 July 2006). Abdullah admits - 'There are still many people who don't understand; they say Pak Lah has lost control. ... That's my way of doing things. Everybody has his way of doing things... The objectives are still the same, there is no change, but the way (of doing it) is my way' (New Straits Times, 18 September 2006). Nevertheless, International Merchant Bank's Merill Lynch states - 'even though the Prime Minister receives constant criticism for being rather slow, doubtful and often bases decisions on overall agreement, his new style of leadership may be exactly what the country needs to rejuvenate the economy's long-term growth prospects, especially in the face of rapid globalisation' (The Star, 8 June 2007).

Abdullah's administrative journey also greatly relies on a team of advisors, consisting of individuals with various backgrounds. This issue has received criticism from several analysts who believe that when the young generation is behind the authority of the Prime Minister, the government may experience a process of self-adaptation with the environment, hence forming an atmosphere of uncertainty. Throughout the past five years, several of Abdullah's principles have been assumed as irrelevant and were constantly and continuously criticised. However, Abdullah deserves to be given time with his team as certain principles can only bear results after a long-term duration. Most of his principles were seen as those focusing on the shaping and growing of individualism and self-entity, and not of physical being.

\subsection{Accommodation}

Accommodation can be referred to as the readiness of the government to listen to views and criticisms on an issue and to ensure that the government is ever ready to serve and to take the necessary measures to ensure better service to the 
public in its aim to create a more people-friendly nation. Among them is the Works Ministry's appeal to the public to assist in overseeing projects as of this year. They can do so by contacting Board of Construction Industry, who will then refer the case of dissatisfaction to the Contractors' Code of Ethics Compliance Monitoring Committee. This is in line with the case of the uncompleted RM565-million project of the Sultanah Bahiyah Hospital in Alor Setar; the deserted RM165 million Kuching prison constructions and the interrupted Johor Customs, Immigration and Quarantine Complex building project valued at RM1.3 billion (New Straits Times, 21 August 2006).

In the Parliament, the formation of several committees has enabled government supporters and opposes to debate more freely and openly, including the formation of the committee to ascertain the guidelines for the code of ethics for Parliament Members (New Straits Times, 8 May 2006). Abdullah sees the role of the Parliament can be made clearer and sturdier by allowing Members of Parliament the opportunity to criticise the government more constructively in order to allow further development of the country. Five years under Abdullah's reign has also shown that besides relying on his team, he has also formed several institutions to mobilise political and social support. To enable public participation, several new institutions including the Parliament Committee have been introduced. This can be seen as the bottom-up basis for political participation.

The most obvious is the input for the 9th Malaysia Plan (9MP) whereby the involvement of various parties has enabled the government to create a mission of national characteristic for the importance and needs of the people. The government has approved RM200 billion for the 9MP projects, an increase of RM30 billion from the 8th MP (The Sun, 19 June 2006). Abdullah has also stated that the BN government would open more venues for the public to be directly involved with the government in deciding how a principle or plan can be interpreted into an action or appropriate measure. Whether or not this rhetorical statement can be shared by the agencies involved until it is moved to the actual principle measure is still being debated.

\subsection{Consensus}

Consensus focuses on the relationship among the government policy makers, implementation agencies and the public. The Prime Minister himself has reiterated many times his belief that every party's opinion must be taken into consideration before reaching a decision on any issue. (Note 12) This is seen by certain parties as a weakness but others are of the opinion of this being an advantage or plus side in coping with the current needs. Almost all Cabinet members today are those who have known and become familiar with Abdullah since earlier times. Abdullah's extensive experience in the Cabinet has in fact allowed the birth of a leadership style which is practised today as everyone sees Abdullah as not only the Prime Minister, but also as a friend as well as colleague.

All these have formed the scope of Abdullah's leadership which leans on discussion and team leadership. Several examples of such a scope include the Independent Police Complaints and Misconduct Commission; money politics which involved high-profiled individuals such as Tan Sri Isa Samad and Tan Sri Kasitah Gaddam; a more assertive, respectable and liberated judicial board; the National Integrity plan and National Integrity Institute; bigger frame of authority to be given to the Backbenchers' Club and Public Accounts Committee.

This style can be looked upon as a means of fencing Abdullah's administrative measures and no doubt the five-year progress and level of performance under Abdullah's leadership will be evaluated based on this style. In measuring Abdullah's administration in a normative context, one of the main elements used by Abdullah is the reliance on cooperation, discussion and teamwork. He also permitted Cabinet members to portray themselves as individuals who were responsible towards their respective ministries whilst each of them is required to function as part of his or her team members.

A similar case can be referred to the minister who is assumed to have two separate and different opinions, bringing on the assumption that the Cabinet is not of a collective basis, but for Abdullah, what is of importance is 'let not there be a difference in substance or content' (Utusan Malaysia, 8 August 2006). A state of confusion was apparent as to whether the minister was speaking on the ministerial capacity or as representing the collective views of his Cabinet. Abdullah was believed to have mentioned - 'I may appear listless and can't make decisions. But Veterans must understand my stand that what I am doing is to help Malays to be more successful ..... he was not out to make money, to feel proud nor to seek popularity from his current position' (The Star, 20 March 2006).

For Abdullah, there is a need of ability to discuss and negotiate no matter what the level or circumstance may be. Furthermore, in the weekly Cabinet meetings, discussions and debates which are of more open characteristics are permitted to facilitate the participation of all Ministers in expressing their views, new ideas in a certain issue brought to the meeting which in turn allows the active involvement or participation of government supporters in the Parliament.

\section{Abdullah's Personality, Leadership and Performance}

In addition, Abdullah is also looked upon as one who possesses a soft personality, and the authority possessed by the Deputy Prime Minister is used in several issues to portray the strength of the Abdullah-Najib affiliation in leading the country. Although each individual of the Cabinet plays an important role and holds great responsibility in their 
respective ministries, the core factor is that overall decision represents a reflection on the team's progress itself under the leadership of its leader, Abdullah. Even with differences of opinions and opposing thoughts among members of the ministry, what is clearly seen is the respective individual loyalty of each member to the administrative capabilities of the Prime Minister.

Abdullah is not an orator but his personality is depicted as less authoritative and more incline to achieve a decision through discussion and not argument. He is not of critical characteristic and is favoured for his modest personality. There are analysts who see Abdullah as one who portrays great patience in persuading, ensuring and debating on an issue critically and not only stating principles based on the strength of Parliamentary support and backing. One of the outcomes we have noticed throughout his five-year administrative reign is to offer encouragement and incentives for the development of a certain matter, as well as to provide resources for such a matter. With this in mind, can Abdullah's actions be questioned for hints of weaknesses and incapability? If his open principles are to be criticised, would this mean that Malaysia would more appropriately be led in an authoritative manner with certain restrictions in participation and accommodation that would further influence the consensus element as well as the discussion as seen in today's leadership? Would Abdullah be obligated to amend his leadership style based on the fact that the people of the nation are more in-line with authoritative leadership and hence complete the vacuum of today's surrounding?

Abdullah believes in the power and authority of the PMO even though collective leadership sentiments do exist. The personality of a leader is essential. There are among those who consider Abdullah weak and overly cautious in making decisions, as well as constantly striving to care for the interests of all parties; then there are those who believe that his background influences his decisions but even more than that, what is obvious throughout the past five years, is that although his personality may be a rather vast contrast from his predecessors, he reiterates that his final aim is to achieve Vision 2020 and encourages its realisation, as well as to head towards Mission 2057, 50 years after independence with a reduction in inflation, a 6 percent annual growth, and a diminishing of federal government deficits as well as a growth and development of foreign investment (Derichs, 2007, p. 154).

Abdullah has tried to rejuvenate the 2004 general elections manifesto and 12 notions which were revealed in his speech as UMNO President in November 2007. The obvious is that the notions were not merely rhetorical but have in fact been launched. Leadership through example, a democratic system based on joint responsibility, development of the human capital, cultivation and search for new economical resources, a nation of trade and industry, the role of private sectors, increase in the quality of the public sector, corruption, enactment and upholding of the law, participation of youth and women, recognition at international level, and national harmony and unity - these form the pulse of this leadership strength. All of these also create the manifesto of the last election which was formed not intending to see its results before the 12th elections but instead as a long-term plan; to cultivate and construct future planning for the country and people under Abdullah's leadership.

The duration of this fifth year has seen good economical growth. Although the increase in the prices of goods and petroleum due to global demands and tenders was unavoidable, yet the country remains stable. There have been no issues of uncertainty. Economic growth is seen as upholding steady development, in accordance with the planning of the National Mission under the 9MP. The value of foreign investment in Malaysia has exceeded the total investment sum for Malaysia abroad as much as RM23 billion, and similarly with foreign assets valued at RM554.3 billion. The Gross Domestic Product (GDP) is at the height of RM153,812 million at the second quarter of the year 2007 and RM144,415 million at the first quarter of 2007. The total export till August 2007 was RM387, 244 million whilst total import stood at RM326, 591 million for the same duration. The industrial product overall index up till August 2007 indicated that it had risen by 1.4 percent with the rate of unemployment standing at 3.4 percent; similarly with several initiatives to prosper the bio-technology and agricultural agenda which is considered to have the capacity to generate the country's economy. An amount of RM6.5 million has been allocated from the 2008 budget for this sector in order to further pursue the growth and development of agriculture-based industry.

By year 2007, Malaysia holds the 24th position as an investment destination to conduct business among 178 countries in the list of the World Bank. The Deutsche Bank has placed Malaysia on the second rung after India as Asian 'Growth Stars' for the duration of 2006-2020 and predicts a 6 percent growth for the coming year. For Forbes, Malaysia possesses a 'wise policy' in order to present a conducive business environment (The Star, 16 November 2007). All these listings are due to the political stability enforced during the administrative reigns of Abdullah.

Several mega projects had also begun their re-planning throughout the fifth year including the structuring of the Felda and Felcra schemes, additions to the LRT railway tracks in the Klang Valley, a double track railway line for Ipoh-Padang Besar, underwater cables for Bakun construction, Trans-Peninsular oil pipelines, a bullet train railway system to Singapore, a West Coast Highway, and a Penang Monorail. The initiative and faith of the Prime Minister to develop the economic sector and to reduce poverty as well as to increase the rates of medium and small industries are also obvious with the launching of the Iskandar Development Region (WPI), the North Corridor Economic Region (NCER) followed by the East Coast Economic Region (ECER) and an economic corridor for Sarawak (Recoda). What 
is clear is that Abdullah has no desire to see the nation left behind in the development of economic corridors (Mingguan Malaysia, 4 November 2007).

\section{Abdullah's Contribution to the Society}

Islam Hadhari, although the concept had been introduced by Dr. Mahathir, it had been promoted as a moderate Islamic concept throughout the five years of Abdullah's administration. Under this banner of Islam Hadhari, further development is carried out including the allocation of RM50, 000 for each Parliamentary area as an activity to be conducted by the constituency council. It does not single out non-Muslim Parliamentary Members who have also been elected to chair the Islam Hadhari constituency committee. The people's representatives play a big role in spreading the agenda of Islam Hadhari as it also stands as a large frame under Abdullah's administration. Foreign communities look upon Malaysia as an exemplary Islamic country among other countries, and this received further positive feedback on the Islam Hadhari principle from President Bush during the recent Asia-Pacific Economic Corporation (APEC) in Sydney, as well as praises from other main global leaders from Australia, New Zealand and Germany. Malaysia continues to hold its relevant position in the world's view mainly as Chairman of the Organisation of Islamic Countries (OIC) regardless of the fact that it can function more effectively. At the United Nations Conference, Abdullah emphasised on how Islam has been wrongly interpreted thus causing war among religions, which was in fact more politically-based and had no actual relevance whatsoever on religion. Malaysia also received the support of West Asia to participate in the Palestine-Israel conference instigated by America recently.

Abdullah has also had bilateral meetings with 13 foreign leaders up till June 2007; whereas 20 visit in 2006; 25 in 2005 and 22 in 2004 with the intention to harmonise international relations. These visits included visits to ASEAN countries, the American and African continents respectively, East Asia, the Middle East and also attending formal meetings. This has enabled Malaysia to gain international recognition as well as contribute to the 19th place among the biggest trade and industry designated countries at global level. As host to the Langkawi International Dialogue (LID) this year, Abdullah and his LID counterparts succeeded in producing an action plan called 'The Way Forward' to abolish poverty among the southern countries.

Abdullah also emphasised on the guidelines for integrity for the country's well-being. He launched two books entitled Corporate Social Responsibility: Our First Look and National Integrity System: A Guiding Framework published by Malaysian Integrity Institute in the effort to develop a government filled with integrity and good administrative capabilities. Bribery continues to be battled with accusations made on various individual backgrounds. Among those which include highly profiled cases but lack of evidence and suspicious witness behaviour often cause these cases to be hard to handle even though until March 2007, as many as 253 cases were investigated by the Anti-Corruption Agency (ACA). As a result, Malaysia was at the 44th place among 163 countries in the Corruption Perception Index (IPR). Abdullah's hopes and faith alone were insufficient in assisting to abolish corruption unless there was a sudden realisation among those involved in such a crime, be it them as the giver or the taker of bribes. Abdullah's characteristic of openness to allow the 2006 audited report be made public calls for praise. He could had initially hidden such wrongdoings within the government agencies itself but by exposing such crimes, ACA could then take action and conduct more detailed investigations. This led to accusations on several officers involved in such crimes even though the public questioned the exact time such sharks would be prosecuted.

The solution for proper and quality effective planning of the civil service as a whole which would simultaneously decrease the number of corrupt activities is an intensive plan for its employees; alongside the principles upheld by the private establishments. All of Abdullah's agenda required a collaboration of agencies which would cooperate in ensuring its success. Abdullah has only the capabilities of planning and allocating responsibilities to the agencies involved. The people involved in the delivery system must instil the spirit of Abdullah's agenda as the spirit of the agency; Abdullah's success is looked upon as the success of all. The accomplishment and success of any principle relied on the interaction among those who formulate the policies, executors and target groups. The government should consider specific incentives in the form of gratuity if these agencies could ensure the success of the Prime Minister's agenda in a short time.

During the fourth year of Abdullah's leadership, civil servants received salary increments which have long been awaited. With other gradual and continuing gratuities and perks, all of Abdullah's visions and plans would materialise. Though small, it would be appreciated, and the delay of implementation would be overcome. A perk or gratuity is not a bribe but is considered a form of motivation to increase productivity. Looking at the journey and achievement of the execution of his agenda including the 9MP, perhaps Abdullah may intend to seek an incantation to alter the public's mindset, contentment with mediocrity, discipline, time and confidence in producing capitalistic individuals of great quality. Abdullah's intensive plan must take into account this matter. This is due to the fact that at times, specific time and ability are required to enhance and build self-realisation. At times, it is not a factor of humanity but more of facts of law, regulations and understanding on what is permitted and what the obstruction seems to be, which may spread over a prolonged period or even cause the interruption of an ongoing execution of a principle or agenda. 
From the perspective of science and technology, Malaysia witnessed the birth of the country's first astronaut at the International Space Station (ISS) which signified the continuum of a project executed by Dr. Mahathir. Dr. Sheikh Muszhaphar Shukor deserves the recognition and praise of the nation. Similarly, the launch of the country's first Scorpene submarine named His Majesty Tunku Abdul Rahman also deserves such praise. In accordance with the country's human capital agenda, the Education Development Main Plan (PIPP) for the duration of 2006-2010 was also executed this year. This new leap in the world of education industry is expected to produce individuals who are educated, skilled and capable, and instilled with values alongside creative and unique characteristics.

The main issue of Abdullah's leadership is that he is constantly compared to leaderships of the past. This is due to the fact that upon his commencement of administration, an abundance of hopes under his position as Prime Minister were imposed on him in different ways based on his style and orientation. In his efforts to bring about changes and his differences in leadership compared to his predecessors, he had a legacy to protect.

Abdullah's leadership style had its risks. Relying on the public, practising a populist approach and style which involved discussion and consensus, enabled him to form an open forum. This further encouraged the birth of views which may seem to oppose the government, thus leading to continuous criticisms and may be interpreted as support to the opposition in the upcoming elections. On the condition that the government obtain such input and believe it can be used in its implementation, it may indeed bring about an increase in support.

Clearly, in Abdullah's reign of power till today, principle values, content and output proves the existence of a continuum but its approaches are different due to the effects of social and political environmental changes. All these can be subsidised and supported by the style in negotiation processes of Abdullah Badawi.

\section{Conclusion}

The difference in his leadership style brings about cause for some to consider it as a weakness and loss of control (Utusan Malaysia, 19 September 2006). The strength and weaknesses of a leader do not rely merely on style but also environmental support toward that individual. In the context of Malaysian political culture, the followers basically remain loyal to the leader who is chosen via traditional traits.

Would physical development instead of inner growth of individual self have more valuable perception among the people and hence prove better in the interest of Abdullah? The ongoing criticism that such an issue would have great effect on Abdullah's entire leadership still lingers. Would we be more comfortable and contented with authoritative-styled leadership and be unable to adapt to Abdullah's openness? Would the moment arrive when Abdullah would assume he would be better off with a change in his leadership style as his patience is continuously tested alongside criticisms that he is in fact a weak leader (New Straits Times, 14 November 2006)? This would further urge him to be firmer in taking less favoured action in the event of being challenged with such accusations (Utusan Malaysia, 10 November 2007).

Perhaps the freedom which exists will be used to criticise the Prime Minister to the point that he would be required to retract and to take control again of such liberty (New Sunday Times, 17 December 2006) or perhaps Abdullah's openness would not be ordained in fulfilling the country's surroundings. There are among critics who are of the opinion that during Dr. Mahathir's leadership, there was never the occurrence of loss of control; and why has Abdullah, who has reigned for five years been forwarded such an accusation? If it is his personality that is being questioned, why does his agenda make it difficult to bring the community closer; is this also an unpopular agenda? Is Abdullah really as weak as he is said to be compared to his rise after 1990; or has Abdullah been weakened by certain indicators to the extent of being labelled as 'losing control'? Why do his counterparts from the BN component party continue to pledge their allegiance and support and faith on his leadership style if he is indeed weak? If he was seen as a replica of Dr. Mahathir, would he be spared of such criticisms?

Abdullah cannot be seen in the likes of President Habibie and President Wahid of Indonesia who indeed had lost control, threatening the reformation agenda; or President Estrada who was incapable of holding onto his position due to corruption. Abdullah also cannot be compared to Goh Chok Tong, a mediocre personality with a heavy burden of succeeding Lee Kuan Yew. Leadership in the Asian region has reflected that what is desired is strong political leadership personality to realise every respective and individual vision.

Consensus, accommodation and participation, all characteristics of Abdullah's leadership style can be made a liability if ordained improperly. Specified decisions on several issues need to be made to ensure continuous stability and consolidation, regardless of them not meeting with the satisfaction of every party. Throughout his five years of ruling, Abdullah has attempted to overcome criticisms of his leadership and to amend several plans in the form of executing such plans. However, he seemed failed to keep the executive power and resigned in 2009 to give away premiership to his deputy, Najib Tun Razak. 


\section{References}

Chamil Wariya. (2004). Abdullah Ahmad Badawi: Perjalanan Politik PM Ke-5. Kuala Lumpur: Utusan Publications.

Derichs, Claudia. (2007). Malaysia in 2006, Asian Survey. Berkeley: University of California. pg. 148-154.

Massa. (2004). February.

Martin, Lipset. (1963). Political Man: The Social Basis of Politics. New York: Anchor.

Max, Weber. (1964). Translated by A.M. Henderson and Talcott Parsons. The Theory of Social and Economic Organization. London: Collin-Macmillan Limited.

Mingguan Malaysia. (2007). 4 November.

Muthiah, Alagappa. (1995). Political Legitimacy in Southeast Asia: The Quest for Moral Authority. Stanford: Stanford University Press.

New Straits Times. (2006). 8 May.

New Straits Times. (2006). 3 June.

New Straits Times. (2006). 9 June.

New Straits Times. (2006). 21 June.

New Sunday Times. (2006). 2 July.

New Straits Times. (2006). 11 August.

New Straits Times. (2006). 21 August.

New Straits Times. (2006). 18 September.

New Straits Times. (2006). 13 November.

New Straits Times. (2006). 14 November.

New Sunday Times. (2006). 17 December.

New Straits Times. (2007). 9 November.

Pandian, S. (2006). 'Pilihanraya Umum Tahun 1999 dan 2004: Perubahan Di Dalam Kesinambungan', in Mohd Fauzi Yaacob. (2006). Malaysia: Menangani Perubahan Dalam Pembangunan. Kuala Lumpur: Universiti Malaya.

The Star. (2006). 20 March.

The Sun. (2006). 19 June.

The Star. (2006). 19 September.

The Star. (2007). 8 June.

The Star. (2007). 13 November.

The Star. (2007). 16 November.

Utusan Malaysia. (2006). 16 January.

Utusan Malaysia. (2006). 8 August.

Utusan Malaysia. (2006). 19 September.

Utusan Malaysia. (2006). 10 November.

Utusan Malaysia. (2007). 16 November.

Utusan Malaysia. (2007). 31 October.

Wan Hashim Wan Teh. (1993). UMNO Dalam Arus Perdana Politik Kebangsaan. Kuala Lumpur: MAHIR Publications.

\section{Notes}

Note 1. From here on referred to as Abdullah.

Note 2. From here on referred to as Dr. Mahathir.

Note 3. Abdullah was the eldest among four siblings, the others being Aminah, Ibrahim and Mohammad Tahir.

Note 4. In the 1978 general elections, Abdullah defeated PAS candidate, Musa Mohd. Yatim with a majority of 5,029 votes.

Note 5. From here on referred to as Anwar Ibrahim. 
Note 6. Abdullah obtained the second highest number of votes with 879 votes compared to Datuk Seri Amar Wan Mokhtar Ahmad and Datuk Seri Anwar Ibrahim, each respectively obtaining 935 and 850 votes. Other candidates who competed but lost were Datuk Rais Yatim - 690 votes, Datuk Seri Ramli Ngah Talib - 667 votes and Datuk Harun Idris -398 votes.

Note 7. Abdullah competed against the candidate from Semangat 46 (S46) under the leadership of Tengku Razaleigh Hamzah. Abdullah won with majority votes of 9,851 defeating the S46 candidate, Ahmad Awang.

Note 8. Obtained the second highest number of votes after Dato' Seri Najib Abdul Razak.

Note 9. Abdullah only agreed to be a candidate after being urged three times to vie for the Kepala Batas Parliamentary seat by Datuk Mohd Noor, the division secretary.

Note 10. Dr. Mahathir personally stated, in a press conference on 7 June 2006, that Abdullah was not of his choosing.

Note 11. The Barisan Nasional won 198 out of 219 parliamentary seats

Note 12. 'I am not the smartest.....there are others who are smarter but I am the Prime Minister and it is not wrong for me to take some time to listen to more views in order to get the best opinion' (New Straits Times, 11 August 2006; Utusan Malaysia, 16 January 2006).

Table 1. Abdullah's Leadership Style and Importance of Principles

\begin{tabular}{|l|l|}
\hline \multicolumn{1}{|c|}{ Leadership Style } & \multicolumn{1}{c|}{ Importance of Principles } \\
\hline Discussion & Continuum of principles \\
\hline Participation & Islam Hadhari \\
\hline Accommodation & Delivery system \\
\hline Encouraging an event & Corruption \\
\hline Team Leadership & Emphasis on 'software' / human capital \\
\hline Consensus & Agriculture; bio-technology \\
\hline & 9th Malaysia Plan, Mission 2057 \\
\hline
\end{tabular}

